\title{
Microcephaly and Zika virus during pregnancy and cephalic perimeter curve
}

\author{
Dora Yasri ${ }^{1}$ \\ (iDViroj Wiwanitkit ${ }^{2}$
}

1. KMT Primary Care Center, Bangkok, Thailand 2. Honorary professor, Dr. DY Patil University, Pune, India

\section{Dear Editor}

We read the publication "Relationship between microcephaly and Zika virus during pregnancy: a review" with a great interest ${ }^{1}$. Santos et al. ${ }^{1}$ mentioned that "Epidemiological data suggest a temporal association between the quantitative increase and the Zika virus epidemic, especially in Northeast Brasil. It is not consensual to measure the cephalic perimeter curve to be considered." Indeed, it is agreeable that there is an observation of the Zika-virus epidemic and microcephaly in Brasil. However, this interrelation is not observed in other endemic areas such as Southeast Asia $^{2}$. The usefulness of cephalic perimeter should be discussed. There is no doubt that the cephalic perimeter can help identify microcephaly, but it cannot help diagnose the etiology of the microcephaly. Aiming at finding a pathological clue for Zika virus infection, a better investigation tool might be transfontanellar ultrasonography ${ }^{3}$. In addition, in a setting where there is a Zika virus epidemic without increased incidence of microcephaly, the usefulness of the cephalic perimeter is reduced if one focuses to specifically use it for the Zika virus infection problem.

Conflict of interest: none

KEYWORDS: Zika Virus. Microcephaly. Pregnancy. palaVRas ChaVE: Zika Virus. Microcefalia. Gravidez.

\section{REFERENCES}

1. Santos GRBD, Aragão FBA, Lobão WJM, Lima FR, Andrade LMRL, Furtado $\mathrm{QR}$, et al. Relationship between microcephaly and Zika virus during pregnancy: a review. Rev Assoc Med Bras. 2018;64(7):635-42.

2. Wiwanitkit V. The current status of Zika virus in Southeast Asia. Epidemiol Health. 2016;38:e2016026.

3. Ximenes ASFC, Pires P, Werner H, Jungmann PM, Rolim Filho EL, Andrade EP, et al. Neuroimaging findings using transfontanellar ultrasound in newborns with microcephaly: a possible association with congenital Zika virus infection. J Matern Fetal Neonatal Med. 2019;32(3):493-501. 